\title{
Influence of Electric Current on Small Intestine of the Rat
}

\author{
J. VOKURKA
}

First Department of Surgery, St. Anne's Teaching Hospital, Faculty of Medicine, Masaryk University, Brno

Received May 6, 2003

Accepted September 22, 2003

\begin{abstract}
Vokurka J.: Influence of Electric Current on Small Intestine of the Rat. Acta Vet. Brno 2003, 72: 553-558.

The aim of this study was to test the effects of monopolar electrocautery (MPEC) on the small intestine of rats. The supply artery of the intestine was subject to electrocautery at various distances from the intestine wall. We evaluated the resulting adhesions in the peritoneal cavity and the effect of MPEC on the serosa, muscular layer and mucosa layer of the small intestine. We found that the number of adhesions increased with the time after MPEC application and that the adhesions arose sooner when MPEC was applied nearer to the intestine. The duration of MPEC also had a strong influence on injury to the serosa. After MPEC application lasting $5 \mathrm{sec}$, the serosa was always injured. After electrocautery at greater distances from the intestine, injury to the muscular layer was visibly lower. Injury to the mucosa decreased with an increasing distance from the cautery site from the intestine. During MPEC that is used in clinical practice we recommend to minimize the time of application and to lower the power. The closer you get from the site of application of MPEC the higher tissue damage may occur. Therefore the use of MPEC in certain anatomical regions has to be very careful (e.g. Calot's triangle).

Monopolar electrocautery, intestine, side effects
\end{abstract}

As early as 1987, convincing biophysical and biochemical evidence was brought by Kurt Semm, one of the pioneers of laparoscopic surgery techniques, suggesting that highfrequency currents cannot be considered completely safe if used in the closed abdominal cavity. Some authors have recommended that electrocautery in certain anatomic regions should be replaced by other techniques, such as thermocoagulation in Calot's triangle (Jurka 1993). In spite of this opinion, monopolar electrocautery (MPEC) has remained the most frequently used coagulation method in both opened and laparoscopic surgery and has been used by approximately $95 \%$ of the operating surgeons (Š efr et al. 1994; Piskač et al. 1995; Olejník 2002).

In 1992, Park described a stenosis of bile ducts after laparoscopic cholecystectomy performed with the use of electrocautery. Problems with monopolar electrosurgery may be caused by unrecognised "stray currents" (Soderstrom 1990; Kala et al. 1996). These problems associated with the use of electrosurgery in laparoscopic applications have not yet been solved completely, by either doctors or engineers (Krška 2001; Olejník 2002; Hoskovec et al 2003).

On the basis of the above-mentioned data in the literature and our own experience, we carried out experiments with the aim of investigating the side effects of monopolar electrocautery in laparoscopic surgery and minimising its undesirable effects.

Materials and Methods

The experimental work was first prepared theoretically by studying data in the relevant literature; then the plan of experiments was approved by the Committee for Ethics of Medical Experiments at Faculty of Medicine, Masaryk University in Brno.

Address for correspondence:

Doc. MUDr. Jiří Vokurka, CSc.

Doc. MUDr. Jirurín Vok klinika,

1. chirurgicka klinika,

Phone: +420543182360

E-mail: vokurka@med.muni.cz

Pekařská 53, 65691 Brno, Czech Republic

http://www.vfucc/acta-vet/actavethtm 
The experiments were performed on healthy rats described as "laboratory rat" or "white rat" (Rattus norvegicus). The weights of individual animals ranged from $150 \mathrm{~g}$ to $540 \mathrm{~g}$, with a mean value of $328 \mathrm{~g}$. A total of 103 animals were included. The experiments were performed in the experimental room of the $\mathrm{I}^{\text {st }}$ Department of Surgery, St. Anne's Teaching Hospital, Masaryk University in Brno. Surgical instruments used in the experiments were, whenever possible, the instruments commonly used in plastic surgery in order to minimise possible secondary injury to tissues and also with respect to the size of the inner organs of the experimental animals.

The rats were operated on the experimental surgery table, fixed on a pad, lying on their backs with upper and lower extremities stretched out. The surgery was performed under general anaesthesia (xylazine with ketamine hydrochloride) and aseptic conditions.

In the experiment, the effect of monopolar electrocautery was tested by applying it on mesenteric arteries at various distances from the abdominal wall. Before the application of monopolar electrocautery, the vessel was constricted with a metal clip in order to simulate the conditions that are usual during laparoscopic surgery. In practice, metal endoclips are used to close large diameter vessels; the clip is electrically conductive. Minor bleeding, occurring in the vicinity of the endoclip, is frequently controlled by electrocautery. During this accidental contact of the active electrode with the endoclip cannot be ruled out.

Monopolar high-frequency surgery can induce harmful stray currents that, under certain conditions, can act at sites distant from the region of the envisaged effects. Secondary undesirable effects often appear at sites where the tissues are compressed or narrowed and also at sites of inadvertent contacts (Soderstrom 1990; Cuschieri 1992; V okurková 1999). Compression of tissues during the preparation or extension with ensuing narrowing can both occur during laparoscopic interventions. In addition, the technique of connecting the active monopolar electrode with the jaws of preparation tongs is often used for electrocautery.

The purpose of the experiment was to test the effects of monopolar electrocautery under special conditions. The rat intestine was selected as the test object because of its easy accessibility. We ensured that the metal clip was applied to an artery, supplying a selected segment of the small intestine and having a diameter of $1 \mathrm{~mm}$, as found by calibration.

After narcotising the animal in the experimental operating room, the upper-medial laparotomy was performed under aseptic conditions. Small intestine loops of the animal were disengaged into the operation wound. A supply artery with a diameter of $1 \mathrm{~mm}$ was selected in the arterial arcades of the mesentery. The artery was constricted with a metal clip placed at a distance of $1 \mathrm{~cm}$ from the intestinal wall. Then the experimental procedure followed: monopolar electrocautery was applied to one of three defined sites (D, E, F) of the chosen mesenteric artery. Site D was in the middle of the distance between the metal clip and the small intestine wall. Its distances from both the clip and the small intestine wall thus amounted to $0.5 \mathrm{~cm}$. Site $\mathrm{E}$ was on the metal clip closing the supplying mesenteric artery. Site F was at a distance of $0.5 \mathrm{~cm}$ from the metal clip in the centripetal direction.

After closing the abdominal cavity, samples for histological examination were taken from animals killed at various, pre-set intervals (see tables). The histological samples were taken from zones of presumed histological changes caused by the application of monopolar electrocautery. Zone B was on the small intestine at the site of the respective mesenteric supply artery. Zones $A$ and $C$ were on the opposite ends of zone $B$. The samples from zones A, B and C were examined histologically for possible changes in the serosa, muscular layer and mucosa layer.

For the statistical eveluation and computer processing of the results, the following software was used: CSS: STATISTICA, company manual of StatSoft Tulsa OK 74104, USA.

\section{Results}

A total of 103 operated experimental animals were included in the experiment. The results obtained were quantified and are shown in Table 1.

After MPEC, the number of adhesions increased in the course of time, the increase being highly significant (Tables 1,2).

The adhesions in site D appeared earlier than in site E, F. After electrocautery, adhesions appeared only around the 30th day at site $\mathrm{E}$ and $\mathrm{F}$ while, at site $\mathrm{D}$, they appeared approximately $10 \mathrm{~d}$ earlier and, in two observations, before d 14 . The differences were statistically highly significant $(P<0.0001)$ (Tables 3,4$)$.

The difference between the effects of different durations of MPEC on the intestine serosa was highly significant. After a 5-second application at site $\mathrm{D}$, the serosa was always injured even in peripheral regions while after MPEC applied for $2 \mathrm{sec}$, the A and C zones were sometimes undamaged (Tables 5, 6).

The effect of duration of MPEC on the muscle layer was not statisticitally significant as 
Table 1

Aggregate table for the statistical evaluation of the effect of MPEC on the intestine

\begin{tabular}{|c|c|c|c|c|c|c|c|c|c|c|c|c|c|}
\hline \multirow{3}{*}{$\begin{array}{l}\mathrm{T} \\
\mathrm{s}\end{array}$} & \multirow[t]{3}{*}{$\mathrm{Z}$} & \multirow{3}{*}{$\begin{array}{l}\text { Time } \\
\text { days }\end{array}$} & \multirow{2}{*}{\multicolumn{2}{|c|}{ Adhesions }} & \multicolumn{9}{|c|}{ Zones $\mathrm{A}+\mathrm{C}$} \\
\hline & & & & & \multicolumn{3}{|c|}{ Serosa } & \multicolumn{3}{|c|}{ muscle } & \multicolumn{3}{|c|}{ mucosa } \\
\hline & & & 0 & 1 & 0 & 1 & 2 & 0 & 1 & 2 & 0 & 1 & 2 \\
\hline 0 & 0 & 14 & 3 & 0 & 3 & 0 & 0 & 3 & 0 & 0 & 3 & 0 & 0 \\
\hline 2 & 4 & 1 & 2 & 0 & 1 & 0 & 1 & 1 & 1 & 0 & 1 & 1 & 0 \\
\hline 2 & 4 & 7 & 7 & 1 & 1 & 1 & 6 & 3 & 3 & 2 & 8 & 0 & 0 \\
\hline 2 & 4 & 14 & 5 & 1 & 1 & 1 & 4 & 5 & 1 & 0 & 5 & 1 & 0 \\
\hline 2 & 4 & 29 & 3 & 2 & 1 & 4 & 0 & 3 & 1 & 1 & 5 & 0 & 0 \\
\hline 2 & 4 & 30 & 1 & 6 & 0 & 2 & 5 & 6 & 0 & 1 & 7 & 0 & 0 \\
\hline 5 & 4 & 20 & 1 & 9 & 0 & 0 & 10 & 7 & 2 & 1 & 10 & 0 & 0 \\
\hline 5 & 5 & 10 & 10 & 0 & 1 & 3 & 6 & 8 & 2 & 0 & 9 & 0 & 1 \\
\hline 5 & 5 & 21 & 20 & 0 & 0 & 7 & 13 & 14 & 5 & 1 & 20 & 0 & 0 \\
\hline 5 & 6 & 11 & 4 & 0 & 0 & 0 & 4 & 4 & 0 & 0 & 4 & 0 & 0 \\
\hline 5 & 6 & 21 & 10 & 0 & 0 & 0 & 10 & 10 & 0 & 0 & 10 & 0 & 0 \\
\hline 5 & 6 & 31 & 3 & 0 & 0 & 0 & 3 & 3 & 0 & 0 & 3 & 0 & 0 \\
\hline 5 & 6 & 42 & 4 & 10 & 1 & 0 & 13 & 12 & 2 & 0 & 14 & 0 & 0 \\
\hline
\end{tabular}

\begin{tabular}{|c|c|c|c|c|c|c|c|c|}
\hline \multirow{3}{*}{$\begin{array}{l}\mathrm{T} \\
\mathrm{s} \\
\end{array}$} & \multirow[t]{3}{*}{$\mathrm{Z}$} & \multirow{3}{*}{$\begin{array}{l}\text { Time } \\
\text { days }\end{array}$} & \multicolumn{6}{|c|}{ Zone B } \\
\hline & & & \multicolumn{2}{|c|}{ Serosa } & \multicolumn{2}{|c|}{ muscle } & \multicolumn{2}{|c|}{ mucosa } \\
\hline & & & 0 & 1 & 0 & 1 & 0 & 1 \\
\hline 0 & 0 & 14 & 1 & 2 & 3 & 0 & 3 & 0 \\
\hline 2 & 4 & 1 & 0 & 2 & 1 & 1 & 2 & 0 \\
\hline 2 & 4 & 7 & 0 & 8 & 0 & 8 & 6 & 2 \\
\hline 2 & 4 & 14 & 0 & 6 & 4 & 2 & 5 & 1 \\
\hline 2 & 4 & 29 & 1 & 4 & 3 & 2 & 3 & 2 \\
\hline 2 & 4 & 30 & 1 & 6 & 2 & 5 & 4 & 3 \\
\hline 5 & 4 & 20 & 0 & 10 & 1 & 9 & 5 & 5 \\
\hline 5 & 5 & 10 & 0 & 10 & 4 & 6 & 7 & 3 \\
\hline 5 & 5 & 21 & 0 & 20 & 4 & 16 & 15 & 5 \\
\hline 5 & 6 & 11 & 0 & 4 & 3 & 1 & 4 & 0 \\
\hline 5 & 6 & 21 & 0 & 10 & 8 & 2 & 10 & 0 \\
\hline 5 & 6 & 31 & 0 & 3 & 3 & 0 & 3 & 0 \\
\hline 5 & 6 & 42 & 0 & 14 & 10 & 4 & 13 & 1 \\
\hline
\end{tabular}

$\mathrm{T}$ - time of MPEC application in the respective parameter $(\mathrm{T}=0$ for the control group with endoclip applied on the mesenteric artery but without MPEC application) in seconds

$\mathrm{Z}$ - parameter of MPEC application on the mesenteric artery:

- monopolar electrocautery was not applied

- monopolar electrocautery was applied in parameter D

- monopolar electrocautery was applied in parameter E

- monopolar electrocautery was applied in parameter $\mathrm{F}$

Time - days between monopolar electrocautery application in the respective parameters and sampling for histological examination

Adhesions - presence or absence of adhesions in the mesentery region adjoining to $\mathrm{D}, \mathrm{E}$ and $\mathrm{F}$ parameters:

- adhesions at the time of sampling not found - adhesions at the time of sampling found

Zones $\mathrm{A}+\mathrm{C}-$ the effect of monopolar electrocautery applied in parameters $\mathrm{D}, \mathrm{E}$ or $\mathrm{F}$ on the serosa, muscle and mucosa of the small intestine found in zones A and C:

- no alterations in the histological picture

lesions either in zone $\mathrm{A}$ or $\mathrm{C}$ found histologically

- lesions both in zones $\mathrm{A}$ and $\mathrm{C}$ found histologically

Zone B - the effect of MPEC applied in parameters D, E or F on the serosa, muscle and mucosa of the intestine found in zone B:

- no alterations in the histological picture - lesions in zone B found histologically 
Table 2

Adhesions after monopolar electrocautery in parameter D, test of days 1-14 against days 29-30
Table 3

Adhesions after monopolar electrocautery in parameter F, test of days 11-21 against days 31-42

CSS/3:

2x2 TABLES CSS/3:

$2 \times 2$ TABLES

$2 \times 2$ table:

\begin{tabular}{|l|l|l|}
\hline 14 & 2 & 16 \\
$50.000 \%$ & $7.143 \%$ & $57.143 \%$ \\
\hline 4 & 8 & 12 \\
$14.286 \%$ & $28.571 \%$ & $42.857 \%$ \\
\hline 18 & 10 & 28 \\
64.286 & 35.714 &
\end{tabular}

Fisher Exact Probability: $\mathrm{p}=0.004800$

Table 4

Adhesions after monopolar electrocautery applied in parameters D/E, days 20-31

CSS/3:

$2 \times 2$ TABLES

$2 \times 2$ table:

\begin{tabular}{|l|l|l|}
\hline 5 & 17 & 22 \\
$11.905 \%$ & $40.476 \%$ & $52.381 \%$ \\
\hline 20 & 0 & 20 \\
$47.619 \%$ & $0.000 \%$ & $47.619 \%$ \\
\cline { 1 - 2 } 25 & 17 & 42 \\
59.524 & 40.476 & \\
\hline
\end{tabular}

Fisher Exact Probability: $p=0.000000103$

Table 6

SEROSA A+C,

$2 \mathrm{~s} / 5 \mathrm{~s}$, parameter D

CSS/3:

$2 \times 2$ TABLES

$2 \times 2$ table:
\begin{tabular}{|l|l|l|} 
& \\
16 & 40 & 56 \\
$21.053 \%$ & $52.632 \%$ & $73.648 \%$ \\
\hline 0 & 20 & 20 \\
$0.000 \%$ & $26.316 \%$ & $26.316 \%$ \\
\hline 16 & 60 & 76 \\
21.053 & 78.947 & \\
\hline
\end{tabular}

Fisher Exact Probability: $\mathrm{p}=0.003846$

$2 \times 2$ table:
\begin{tabular}{|l|l|l|}
\hline 14 & 0 & 14 \\
$45.161 \%$ & $0.000 \%$ & $45.161 \%$ \\
\hline 7 & 10 & 17 \\
$22.581 \%$ & $32.258 \%$ & $54.839 \%$ \\
\hline 21 & 10 & 31 \\
67.742 & 32.258 & \\
\hline
\end{tabular}

Fisher Exact Probability: $\mathrm{p}=0.000438$

Table 5

Adhesions after monopolar electrocautery applied in parameters D/E, days 20-31

\section{CSS/3:}

$2 \times 2$ TABLES

2 x 2 table:

\begin{tabular}{|l|l|l|}
\hline 5 & 17 & 22 \\
$14.286 \%$ & $48.571 \%$ & $62.857 \%$ \\
\cline { 1 - 2 } 13 & 0 & 13 \\
$37.143 \%$ & $0.000 \%$ & $37.143 \%$ \\
\cline { 1 - 2 } 18 & 17 & 35 \\
51.429 & 48.571 & \\
\hline
\end{tabular}

Fisher Exact Probability: $\mathrm{p}=0.000006$

Table 7

Parameter D/

parameter $\mathrm{F}$

$2 \times 2$ TABLES

$2 \times 2$ table:

\begin{tabular}{|l|l|l|}
\hline 16 & 4 & 20 \\
$19.512 \%$ & $4.878 \%$ & $24.390 \%$ \\
\hline 60 & 2 & 62 \\
$73.171 \%$ & $2.439 \%$ & $75.610 \%$ \\
\hline 6 & 6 & 82 \\
92.683 & 7.317 & \\
\hline
\end{tabular}

Fisher Exact Probability: $\mathrm{p}=0.029021$

far as injury in site individual zones was concerned. However, the injury was less severe after MPEC was applied to $\mathrm{F}$, as compared with both $\mathrm{D}$ and $\mathrm{E}$ sites $(P<0.05)$ (Table 7).

The musoca was undamaged in zones $\mathrm{A}$ and $\mathrm{C}$ in almost all cases; therefore, there was no point in statistical evaluation. After electrocautery at sites $\mathrm{D}$ and $\mathrm{F}$ or $\mathrm{E}$ and $\mathrm{F}$, the differences were statistically significant $(P<0.01$ or $P<0.05$, respectively). The injury to the mucosa decreased with an increase in distance between the cautery site and the intestine. After cautery at site $\mathrm{F}(0.5 \mathrm{~cm}$ from the metal clip in the centripetal direction), the extent of injury was only slightly significant (Tables 8,9 ). 
Table 8

Comparison of monopolar electrocautery in parameters $\mathrm{D} / \mathrm{F}$
Table 9

Comparison of monopolar electrocautery in parameters $\mathrm{E} / \mathrm{F}$

$2 \times 2$ TABLES

2x2 TABLES CSS/3:

$2 \times 2$ table:

\begin{tabular}{|l|l|}
\hline 22 & 8 \\
$36.066 \%$ & $13.115 \%$ \\
\hline 30 & 1 \\
$49.180 \%$ & $1.639 \%$ \\
\hline 52 & 9 \\
85.246 & 14.754
\end{tabular}

31

$50.820 \%$

61

Fisher Exact Probability: $\mathrm{p}=0.011288$

Fisher Exact Probability: $\mathrm{p}=0.001784$

\section{Discussion}

Living tissue in an electric field behaves as a special type of conductor. It is different from both metal conductors and electrolytes due to its macroscopic and microscopic non-homogenity (Tucker et al. 1992). The electric current flowing through the tissues passes through the media of various chemical composition, viscosity and structure. These involve, for example, the cell membranes and cytoplasmic structures, intercellular media, etc. (Voyles and Tucker 1992).

Each of these media is characterised by a specific conductance; the specific conductances of intercellular spaces and cell cytoplasm are similar, but the conductance of cell membranes is, on average, 106 to 108 times lower. The electric conductance of tissues is predominantly mediated by ions, i.e. electrolytically. Unlike standard conductors, the ohmic resistance of tissues is not constant. Its value decreases during the flow of electric current. The electric resistance of tissues also depends on their functional state: a lack of oxygen results in increased resistance, which, at first, is reversible. The arrest of living processes results in a decrease in the conductance. When a high-frequency current of sufficient intensity passes through cell liquid from the active to the neutral electrode, heat generation is so rapid that steam generated within the cells breaks the cell membranes. This effect is generally used in surgery for incision or coagulation of tissues. Therefore, electric surgery units are equipped with high-frequency apparatus that permits the destruction of tissue cells.

As recently described, a number of different situations occur in surgery when undesirable secondary burns may appear during the use of electric current (Š efr et al. 1995; V y sloužil et al. 2000; Rovný et al. 2002). But two physical principles are clear: firstly, the current flows through paths of lowest resistance and, secondly, if the current is strong enough, burns appear. Providing the current is high and the corresponding voltage low, the current may be supressed or flow through other paths with lower resistance (Soderstrom 1990).

In our experimental work, we showed that the number of adhesions in the mesenteric region adjoining the site of MPEC application increased with the duration of MPEC application. When MPEC was applied to the mesenteric artery nearer to the intestine, the adhesions developed sooner. When MPEC was applied to the mesenteric artery at site D for $5 \mathrm{sec}$, the serosa of the small intestine was always injured; when it was applied for only $2 \mathrm{sec}$, the peripheral zones were sometimes left intact. MPEC applied at more remote sites resulted in significantly less injury to the muscle layer of the small intestine of the experimental animal. Injury to the mucosa decreased with an increasing distance of the cautery site from the intestine. The decrease was significant when the cautery was applied to site F (above the clip).

During MPEc that is used in clinical practice we recommend to minimize the time of application and to lower the power. The closer you get from the site of application of MPEC the higher tissue damage may occur. Therefore the use of MPEC in certain anatomical regions has to be very careful (e.g. Calot's triangle). 


\section{Monopolární elektrokoagulace a tenké stfievo u potkana}

V experimentu byl testován účinek monopolární elektrokoagulace na tenké střevo $\mathrm{u}$ potkana. $\mathrm{Na}$ výživnou tepnu střeva bylo působeno elektrokauterem $\mathrm{v}$ různých vzdálenostech od střeva. Byly hodnoceny srůsty vzniklé v peritoneální dutině a vliv monopolární elektrokoagulace na serózu, tuniku muskuláris a mukózu tenkého střeva. Bylo zjištěno, že množství srůstů stoupá v závislosti na času po monopolární elektrokoagulaci. Srůsty vznikaly tím dřive, čím blíže střevu byla monopolární elektrokoagulace použita. Délka monopolární elektrokoagulace měla také velký vliv na poškození serozy. Po aplikaci monopolární elektrokoagulace $\mathrm{v}$ délce $5 \mathrm{~s}$ byla seróza vždy poškozena. Po působení elektrokauteru ve větší vzdálenosti od střeva bylo poškození svalové vrstvy střeva signifikantně menší. Poškození sliznice stř̌eva klesá s rostoucí vzdáleností parametru pálení od střeva. Významný pokles nastává při pálení v parametru F (nad svorkou). Proto při použití monopolární elektrokoagulace v klinické praxi doporučujeme zkrátit dobu její aplikace na minimum a využít nízkou energii. Nebezpečí poškození tkání vzrůstá se zmenšující se vzdáleností od místa aplikace monopolární elektrokoagulace. Proto by se měla monopolární elektrokoagulace používat v určitých anatomických lokalizacích velmi opatrně (např. Calotův trojúhelník).

\section{Acknowledgement}

The author wish to express his thank to doc. RNDr. V. Znojil, CSc. from the Centre of Mathematic Modelling, Department of Pathophysiology, medical faculty, Masaryk University Brno for his help with statistic evaluation and computer processing of the results.

\section{References}

CUSCHIERI, A, BUESS, G, PÉRISSAT, J 1992: Operative manual of endoscopic surgery. Springer-Verlag Berlin, Heidelberg, New York, pp. 44-60

HOSKOVEC, D, JAROŠ, K, HLEDÍK, E, SCHAUTA, M 2003: Iatrogenní léze žlučových cest. Možnosti terapie a dlouhodobé výsledky léčby. Bulletin HPB 11: 63-65

JURKA, M, SKŘIČKA, T, LEYPOLD, J 1993: Laparoskopická cholecystektomie. Petřivalského nadace, Brno, p. 207

KALA, Z, VOMELA, J, HANKE, I, ŠILHART, Z, KLEINBAUER, A, RŮŽIČKA, M 1996: Retroperitoneoskopická lumbální sympatektomie. (Retroperitoneoscopic lumbar sympatectomy). Rozhl Chir 75: 157-160

KRŠKA, Z a kol. 2001: Miniinvazívní intervenční medicína. Triton, Praha, p. 175

OLEJNÍK, J 2002: Haemostasis in upper gastrointestinal tract - competence problem. Lek Obz 51: 37-41

PARK, HY, OSKANIAN, Z 1992: Obstructive jaundice after laparoscopic chlecystectomy with electrocautery. Am J Surg 58: 321-323

PISKAČ, P, RIEBEL, O, JURKA, M, VOKURKA, J 1995: Urgentní endoskopická papilosfinkterotomie na chirurgickém pracovišti. Čs a slov gastroenterol 49: 3-6

ROVNÝ, A, ROVNÝ, F, ŘEHOŘEK, P, ŠABACKÝ, I, DRÁBEK, M, BORIS, P 2002:Využití appendixu při tvorbě kontinentního mechanizmu derivace moče. Čs urol 4: 32-35

SEMM, KF, FRIEDRICH, ER 1987: Operative manual for abdominal endoscopic surgery. Chicago, London Yearbook Medical Publishers Inc., p. 90

SODERSTROM, RM 1990: Electrosurgery's advantages and disadvantages. Special issue Technology. Contemp Ob Gyn 35: $35-47$

ŠEFR, R, OCHMANN, J, KOZUMPLÍK, L, VRASTYÁK, J 1994: 150 consecutive laparoscopic cholecystectomies performed by surgical resident during one year. Surg Endosc 8: 261

ŠEFR, R, PENKA, I, OLIVERO, R, JAGOŠ, F, MUNTEANU, A 1995: The impact of laparoendoskopic surgery on the training of surgical residens. Intern Surg 80: $356-357$

TUCKER, RD, VOYLES, CR, SILVIS, SE 1992: Capacitive coupled stray currents during laparoscopic and endoscopic electrosurgical procedures. Biomed. Instrument and Technology 26: 303-311

VOKURKOVÁ, J 1999: Rozštěpové vady obličeje. Thesis LF MU Brno, p. 93

VOYLES, CR, TUCKER, RD 1992: Enducation and engineering solutions for potential problems with laparoscopic monopolar electrosurgery. Am J Surg 164: 57-62

VYSLOUŽIL, K, KRÁL, V, NEORAL, Č, KLEMENTA, I, BLAHUT, L, KONEČNY, M 2000: Chirurgické léčení spontánní perforace jícnu - Boerhaave syndromu. Rozh Chir 79: 521-523 